\title{
(Pseudo)cleft constructions in old Romanian
}

\author{
Mihaela Gheorghe* \\ Faculty of Letters, "Transilvania" University of Brașov, Bd. Eroilor 29, 500036 Brașov, Romania \\ "Iorgu Iordan - Al. Rosetti" Institute of Linguistics, Calea 13 Septembrie 13, 050711 Bucharest, Romania
}

\section{Article info}

History:

Received May 9, 2017

Accepted May 13, 2017

Published September 30, 2017

Key words:

cleft sentences

pseudo-cleft sentences

relative clauses

old Romanian

\begin{abstract}
The article examines the syntactic and semantic features of cleft sentences in Old Romanian (OR) as compared to Modern Romanian (MR). The clefting strategy in MR can only produce pseudo-cleft constructions (identifying structures with free relative clauses headed by ce, or relative clauses with an antecedent; the focalized constituent follows the relative clause and the copula; the reversed pattern is also possible: the focalized constituent is placed before the copula and the relative clause). The analysis of an OR corpus showed that cleft constructions were quite frequent, but the patterns were more diverse than in MR: besides cleft and pseudo-cleft constructions, OR also employed hybrid constructions, that amalgamate the features of the prototypical clefts.
\end{abstract}

\section{Introduction}

Since Jespersen (1937/1984), an extensive literature deals with the description of cleft sentences. Most of the studies are dedicated to the syntax of clefts (Akmajian, 1970; Gundel, 1977; Higgins, 1979; Boškovic, 1997; Iatridou \& Varlokosta, 1998; Reeve, 2011, 2012; Hartmann \& Tonjes, 2013; Hedberg, 2013), but also to their semantic and pragmatic properties (see Prince, 1981; Declerck, 1984, 1988; Halliday, 1985; Lambrecht, 2001).

This paper focuses on the distinction in the current syntactic theory between clefts and pseudo-clefts.

The general organization of a prototypic cleft construction (1) is [expletive + copula + FOCALIZED XP + restrictive relative clause] (Reeve, 2012, p. 1), where the focalized XP may be a subject (1a) or an object (1b).

(1) a. It was JoHN who left.

b. It was A RED BAG that I bought.

The general schema of a pseudo-cleft (2) is [relative clause + copula + FOCALIZED XP] , and it can be organized as in (2a), or in the reversed pattern (2b): [FOCALIZED XP + copula + relative clause] (see Huddlestone et al., 2002, p. 1414). In a narrow perspective, pseudo-clefts are considered to be free relative clauses that belong to identification patterns in which they occupy a thematic position, as in (2a,b) (see Prince, 1978, p. 883); in a wider view, the class of pseudo-clefts may include relative clauses with a neutral antecedent as (fact/manner/place/reason, etc.) (2c), or relative clauses with a universal quantifier antecedent (2d) (Collins, 1991, p. 27), with the following general organization: [FOCALIZED XP + copula + antecedent + relative clause].

(2) a. What I bought was a red bag.

b. A red bag was what I bought.

c. The place where John saw Mary was in front of the bank.

d. All he wanted was a hamburger.

\footnotetext{
*Email address:m.gheorghe@unitbv.ro.
} 
The paper aims to present an inventory of cleft sentences patterns in Old Romanian (OR), and to confront it with the cleft patterns that are employed in Modern Romanian (MR).

Most descriptions of Romanian clefts (Șerbănescu, 1996; Pană Dindelegan, 2013, p. 488) show that the clefting strategy in MR can only produce pseudo-clefts; they are either identification structures ([relative clause + copula + FOCALIZED XP]) with free relative clauses headed by ce (3a), or relative structures with an antecedent that has the properties mentioned by Collins (1991; see supra): a noun with generalizing value $(3 \mathrm{~b}, \mathrm{c})$ or the universal quantifier tot $(3 \mathrm{~d})$; this structure matches the pattern: [antecedent + relative clause + copula + FOCALIZED XP].

Reversed pseudo-clefts are also possible in Romanian. The focalized constituent is extracted from subject position (4a) or direct object / prepositional object / adjunct position (4b); the pattern of such constructions is: [FOCALIZED XP + copula + antecedent + relative clause $]^{1}$.

(3) a. [Ce mă supără cel mai tare $]$ este Că NU AI RĂBDARE. what CL.ACC.1SG upsets most hard is that not have patience 'What upsets me most is that you have no patience'

b. Ceea [ce mă supără cel mai tare] este Că NU AI that what CL.ACC.1SG upsets most hard is that not have RĂBDARE.

patience

'What upsets me most is that you have no patience'

c. Chestia [care mă supără cel mai tare] este Că NU thing.DEF which CL.ACC.1SG upsets most hard is that not AI RĂBDARE.

have patience

'The fact that upsets me most is that you have no patience'

d. Tot [ce mă supără] este Că NU AI RĂBDARE. all what CL.ACC.1SG upsets is that not have patience 'All that upsets me is that you have no patience'

(4) a. Că NU AI RĂBDARE este ceea $[$ ce mă supără that not have patience is that what CL.ACC.1sG upsets cel mai tare]. most hard 'That you have no patience upsets me most'

b. EL este cel [pe care l-ai întîlnit he is the.one DOM which CL.ACC.3SG=AUX.have.2SG meet.PPLE ieri]/ [despre care am vorbit $] /$ [la care yesterday about which AUx.have.1PL speak.PPLE to which ne ducem].

CL.REFL.ACC.1PL go

'He is the one that you met yesterday / we were talking about / we are going at'

\footnotetext{
${ }^{1}$ Though not yet supported by quantitative analysis, an observation should be made: the pattern [FOCALIZED XP + copula + relative clause] is almost absent in $\mathrm{MR}$ (or, more precisely, it is limited to the situations in which the focalized constituent is an object, and the relative clause is headed by $c e$, with a marked preference for the antecedent construction [FOCALIZED $X P+$ copula + antecedent + relative clause $]$. Compared to the patterns under $(3 \mathrm{~b}-\mathrm{d})$, the pattern $[$ relative clause + copula + FOCALIZED XP], in which the relative clause has a general nominal antecedent, also seems to have a limited distribution. The pattern favours $c e$ as the head of the relative clause, and the focalized constituent is usually an object. Both cleft constructions are in free variation with the variant in which the relative clause has the pronominal antecedent ceea. This remark may lead to the conclusion that, in fact, the headless relative clause is a variant of the construction with ceea. For further detail regarding the distribution of (ceea) ce in MR relative clauses, see Gheorghe (2004, p. 140-148).
} 


\section{Cleft patterns in Old Romanian}

The investigation of a corpus of Romanian $16^{\text {th }}-18^{\text {th }}$ century texts revealed the existence of many structures in which the focalization of a constituent is the result of a clefting mechanism. The cleft constructions identified in these texts are different from the clefts in MR, in terms of their general organization and in terms of morpho-syntactic features (that will be discussed below); the analysis of the corpus also showed that the pseudo-cleft pattern illustrated in $(3 \mathrm{a}-\mathrm{d})$, and the reversed pattern in (4a) are both absent in OR.

\subsection{Cleft sentences}

The corpus revealed the existence of cleft patterns that are similar to the prototypical ones (which are known to be impossible in MR), and they are organized under the pattern [copula + FOCALIZED XP + relative clause]. The structures in (5) are similar to the ones in (1), with the only difference that they lack the expletive pronoun. The corpus displays a great variety of constructions, both in terms of the syntactic position of the focalized constituent [subject in $(5 \mathrm{a}, \mathrm{d}, \mathrm{e})$, adjunct in $\left(5 \mathrm{~b}_{1}\right)$ and prepositional object in $\left.\left(5 b_{2}, c\right)\right]$, and in terms of the choice of the relative connector. Moreover, the focalized XP may have a simple structure [proper name or demonstrative $(5 \mathrm{a}, \mathrm{b})]$, or a complex structure $(5 \mathrm{c}, \mathrm{d}, \mathrm{e})$. The complex focalized constituent has a pronominal antecedent and a restrictive relative clause (bearing the focal information). The relative clause may also have a pronominal antecedent $(5 \mathrm{f})$.

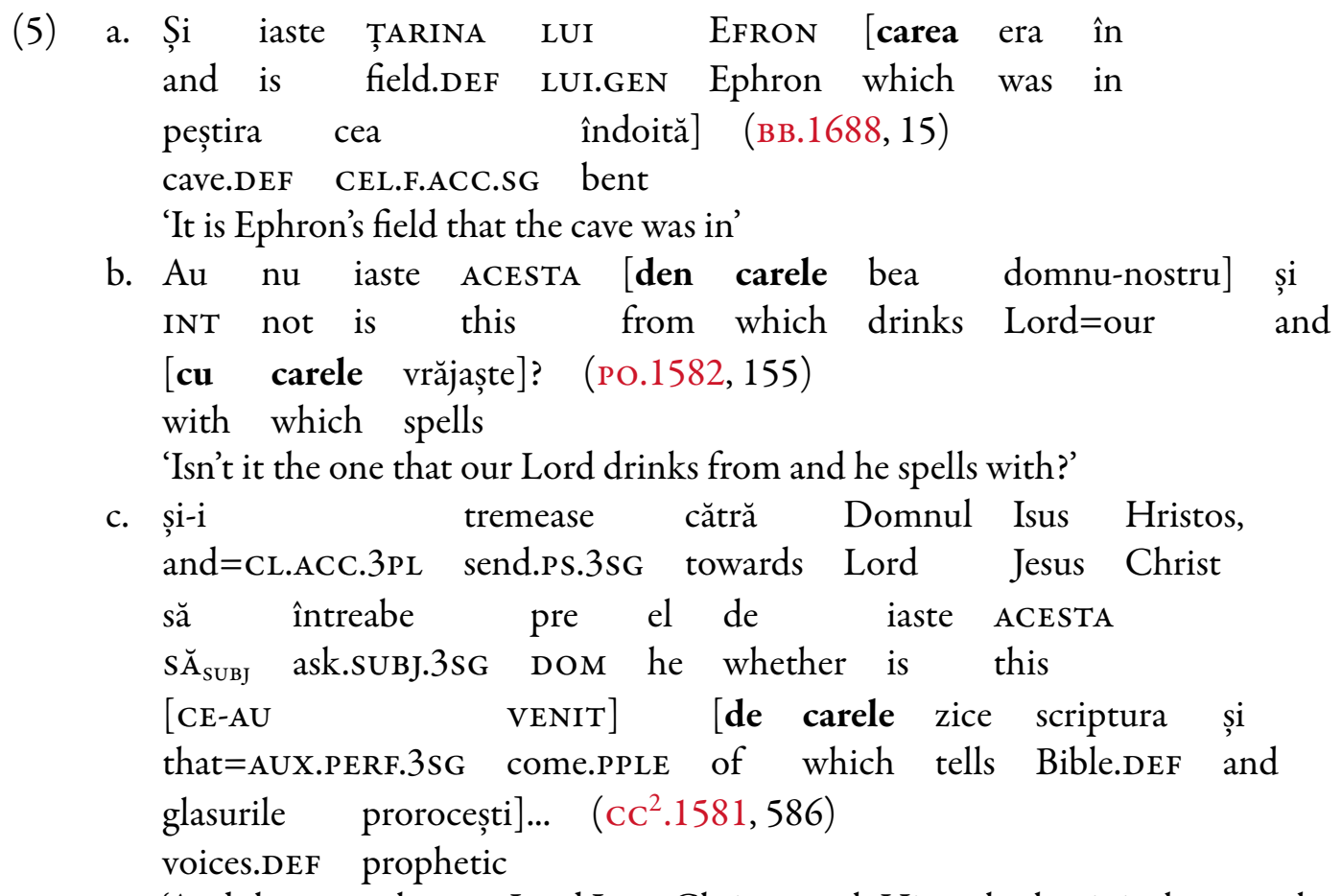

'And they sent them to Lord Jesus Christ, to ask Him whether it is the one who came that the Bible tells about'

d. De nu ACESTA, au iaste CELA [CE RĂSIPIIA ÎNTRU

if not this or is that who wonder.IMP.3sg in

IERUSALIM] [cine meniia numele acesta...]? (св.1559-60, 98)

Jerusalem who fate.IMP.3sg name.DEF this

'If it is not this one, is it the one that wondered in Jerusalem who was destined to bear this name?'

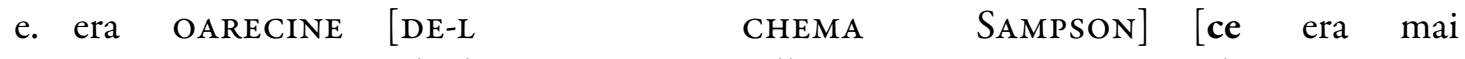
was someone which=CL.ACC.3sG call.IMP.3sg Samson who was more $\mathrm{cu}$ vîrtute de toț cîţi era pe lume] (FD.1592-604, 568 ${ }^{\mathrm{r}}$ ) with virtue than all how.much were on Earth 
'It was someone called Samson who was most virtuous on Earth'

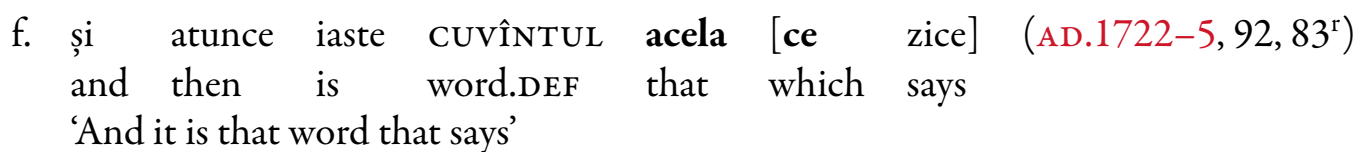

\subsection{Prototypical pseudo-clefts}

The prototypical pseudo-cleft pattern [FOCALIZED XP + copula + relative clause], with the relative pronoun $c e$ and with a focalized constituent in object position (see discussion in footnote 1 ), which is almost absent in MR, or at least reduced to a single pattern, is very well represented in the OR corpus.

The examples under (6) show that in OR the patterns are more diversified than in MR. On the one hand, the focalized XP may occur in subject position, on the other hand, the relative clause may have other connectors besides $c e$ [see $(6 \mathrm{a}, \mathrm{c}, \mathrm{d})]$ :

(6) a. Că TU ești [cinre me-au trasu that you are who CL.ACC.1SG=AUX.have.2SG pull.PPLE de $\quad$ zgău $](\ldots) \quad($ PH.1500-1510, 103, 17²)

of belly

'It is you who pulled me through'

b. Știa-l el că ACESTA era [ce derept know.IMP.3SG=CL.ACC.3SG he that this was what as

milosteniia ședea pre lîngă înfrunsețatele uși ale mercy.DEF sit.IMP.3SG around embelished doors of besearecilor] (CP.1570,29)

churches

'He knew that it was this one who would sit around the embellished doors of the churches'

c. Că (...) ACELA iaste [de-1 măreaște Domnul $]\left(\mathrm{CC}^{2} .1581,556\right)$ that that is who=CL.ACC.3sG praises Lord.DEF 'That that is the one who is praised by God'

d. Că ACEsta amu iaste [care de el e scris] $\left(\mathrm{CC}^{2} .1581,590\right)$ that this now is which by him is written

'That this is the one which was written about'

The examples under $(7 \mathrm{a}, \mathrm{b})$ have focalized proper names, numerals (7c), and complex DP $(7 \mathrm{~d})$ extracted from subject position. Such constructions can be found in MR only with an antecedent relative clause.

(7) a. Minea proroc iaste [de-au prorocit de Mihea prophet is who=AUX.have.2SG predict.PPLE of aceasta] $\quad\left(\mathrm{CC}^{2} .1581,562\right)$

this.F.ACC

'It is Mihea the prophet who predicted this'

b. PAVEL iaste [carile mărturisește adevărata a Domnului

Pavel is who confesses true AL.GEN Lord

făgadă] (...) $\quad($ CD.1698, 164)

promise

'It is Paul who confesses the true promise of the Lord'

c. DoAo era [de ținea ruda omenească]: dulceaţa și two were that keep.IMP.3sg kind human pleasure.DEF and scîrba. $\quad\left(\mathrm{CC}^{2} .1581,520\right)$

disgust.DEF

'There were two things that drove humankind: pleasure and disgust' 
d. că NUMAI SINGURă DREPTATEa iaste [de-i face that only alone justice is which=CL.ACC.3PL makes cinstiţ la norod]. (AD.1722-5, 86, $\left.78^{\mathrm{r}}\right)$ praised for people

'It is only justice that makes them praised by the people'

The corpus also revealed examples in which the focalized constituent is extracted from direct object $(8 \mathrm{a}, \mathrm{b})$ or prepositional object $(8 \mathrm{c}, \mathrm{d})$ positions; in these examples, too, the relative connector can be other than ce:

(8) a. Și acum, ACEASTA iaste [care te rog, Doamne and now this is which CL.ACC.2sG ask Lord.voc împărate], și [care cer de la tine]! (вв.1688, 644) emperor.voc and which ask from you 'And now, it is this that I ask you, Lord, and that I ask from you'

b. Aceasta iaste [ce dzice Pavel apostol să să this is what says Paul disciple S. $\breve{A}_{\text {SUB }}$ CL.REFL.3sG socotească omul sîngur pre sine] (CazV.1643, 43 $\left.3^{\mathrm{r}}\right)$ think man.DEF by.himself on him 'It is this that Paul the disciple says that people should reflect upon'

c. Aceasta iaste [care au zis Domnul] (BB.1688,76) this is what AUX.have.2sG say.PPLE Lord.DEF 'It is this what the Lord said'

d. Deaci ACEA iaste $[$ de ce grăim de stepena întăia a so that is of what speak of master first AL.GEN tatălui...] (Prav.1581, 167, 220v)

father.GEN.DEF

'So it is this what we say about the first master of our father'

\subsection{Reversed pseudo-clefts}

In the OR corpus, the most frequent are the examples in which the focalization of a constituent employs the reversed clefting strategy, as in (4b): [FOCALIZED XP + copula + antecedent + relative clause]). As far as the XP under focus is concerned, the corpus analysis revealed the frequency of personal pronouns $(9 \mathrm{a}-\mathrm{c})$, demonstratives (9d-f) and pro-phrase demonstratives $(9 \mathrm{~g})$, indefinites (9h), and proper nouns (10), all of them well represented in all stages of the OR.

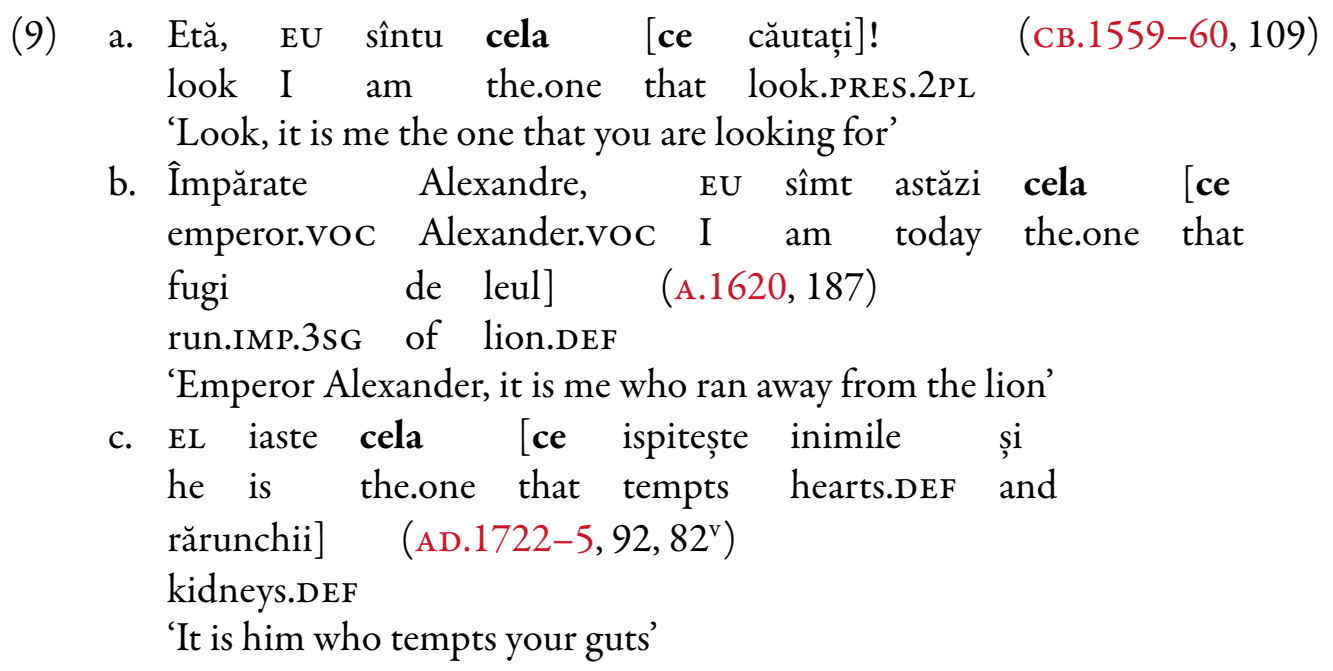


d. ACESTA e cela [ce împărăția răsărita și this is the.one that rule.IMP.3SG East.DEF and

apusul]. $\quad\left(\right.$ FD.1592-604, 483 ${ }^{\text {r }}$

West.DEF

'This is the one who ruled the world'

e. $\mathrm{Au}$ nu iaste ACESTA cela [ce ședea de IMP not is this the.one that sit.IMP.3sG and cerea]? $\quad\left(\mathrm{CazV} .1643,168^{\mathrm{r}}\right)$

beg.IMP.3SG

'Isn't he the one who sit there and begged?'

f. Cela ce are poruncile mele și le păzește the.one who has rules.DEF my and CL.ACC.3PL keeps pre iale, ACELA iaste cela $[$ ce mă DOM them.F.ACC that is the.one who CL.ACC.1sG iubește] (AD.1722-5, 79, 71 $\left.{ }^{\mathrm{v}}\right)$

loves

'It is the one who keeps my rules that loves me'

g. Și ACEASTA iaste aceia [ce zice prorocul and this is that what says prophet.DEF Ioil] (AD.1722-5, 219, 200 $\left.{ }^{\mathrm{v}}\right)$

Ioil

'And it is this what says Ioil the prophet'

h. că ALTUL iaste cela [ce samănă], și ALTUL $\sqrt{ }$ that another.one is that that seeds and another

cela $[$ ce seaceră $] \quad\left(\mathrm{CazV} .1643,160^{\mathrm{r}}\right)$

that that harvests

'It is one who seeds and it is another one who harvests'

a. SAVL

era acesta $[$ ce vrea uciderea

lui] (св.1559-60, 81)

Savl.NOM was this that want.IMP.3sG killing.DEF his 'It was Savl the one who wanted him killed'

b. SAvel era cela [ce vrea uciderii lui] (CP.1570,81) Savel.NOM was that that want.IMP.3sg killing.DAT his 'It was Savel the one who wanted him killed'

c. Că DumnezăU iaste Cel [ce zdrobeaște războaiele] $($ вв.1688, 632) for Lord is the.one that crushes wars.DEF 'It is God who breaks the wars'

d. Duse-se omul și vestiia jidovilor go.PS.3SG=CL.REFL.3SG man.DEF and announce.IMP.3SG Jews.DAT că IIsus iaste Cela $[$ ce l-au that Jesus is the.one that CL.ACC.3SG=AUX.have.3sG făcut pre el sănătos] (Bв.1688, 816) make.PPLE DOM he healthy 'The man went to announce the jews that it was Jesus the one who made him well'

e. IIsus iaste cela [ce m-au făcut Jesus is the.one that CL.ACC.1SG=AUX.have.3sG make.PPLE sănătos] (CazV.1643, 151 $\left.{ }^{\mathrm{v}}\right)$ healthy 'It was Jesus the one who made me well' 
f. Cunoașteți dară că Domnul iaste Cel know.PRES.2PL therefore that Lord.DEF is the.one [ce au turburat $]$ (вв.1688,371)

that AUX.have.3sg trouble.PPLE

'You know that it is the Lord the one who has been disturbed'

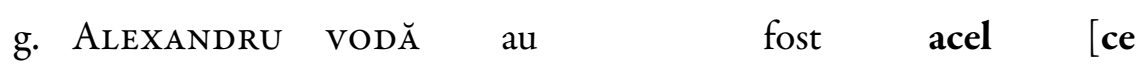
Alexander the.ruler AUX.have.3sg be.PPLE the.one that s-au bătut cu Pătru vodă CL.REFL.3SG=AUX.have.3sG fight.PPLE with Pătru the.ruler Aron] (AU.1700, 53)

Aron

'It was Alexander the ruler who fought Petru Aron the ruler.'

\subsection{Hybrid pseudo-clefts}

A hybrid variant of cleft construction can be found in the examples under (11). The pattern amalgamates two structures: the prototypical cleft (with overt subject instead of an expletive) and the reversed pseudocleft. The focalized constituent is included in a predication of identification, which makes difficult the reconstruction of its relationship to the extraction position. As an argument for the amalgamated structure, see the hesitation regarding the person agreement in (11a) vs. (11b). The schema proposed for these constructions is [overt subject + copula + FOCALIZED XP + antecedent + relative clause]). Though the prototypical patterns are altered, these examples should also be considered clefts, due to the emphatic value of the construction.
a. Eu sîntu Isus, cela
[ce-1
tu
gonești] (св.1559-60, 93)
I am Jesus the.one that $=$ CL.ACC.3SG you banish
'I am Jesus, the one that you banish'

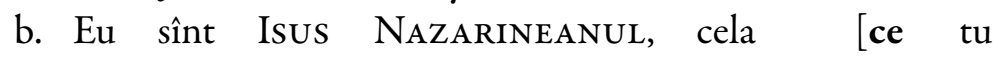
I am Jesus from.Nazareth the.one that you
mă
gonești] (CP.1570, 93)
CL.ACC.1SG banish

'I am Jesus from Nazareth, the one that you banish'
c. Acela iaste Moisi cela [ce zise fillor lu
that is Moses the.one that say.PS.3SG sons.DAT LUI.GEN
Israil] (Св.1559-60,75)

Israel

'It is Moses the one who told Israels sons'

d. Acesta iaste Hristos, Isus cela [ce-1

this is Christ Jesus the.one that $=$ CL.ACC.3sG

spuiu eu voao] (Св.1559-60, 181)

tell.PRES.1SG I you.DAT.2PL

'It is Jesus Christ the one that I am telling you about'

e. Acela iaste Isus Hristos [ce elu-l eu

that is Jesus Christ that he.ACC $=$ CL.ACC.3SG I

spuiu voao $\quad$ (CP.1570, 181)

tell.PRES.1sG you.DAT.2PL

'It is Jesus Christ the one that I am telling you about'

$\begin{array}{llllll}\text { f. acela } & \text { iaste } & \text { ILIE } & {[\text { cela }} & {[\text { ce va }} & \text { să } \\ \text { that is } & \text { Elias the.one that } & \text { AUX.want.3sG } & \text { S̆ }_{\text {sUbJ }}\end{array}$ 


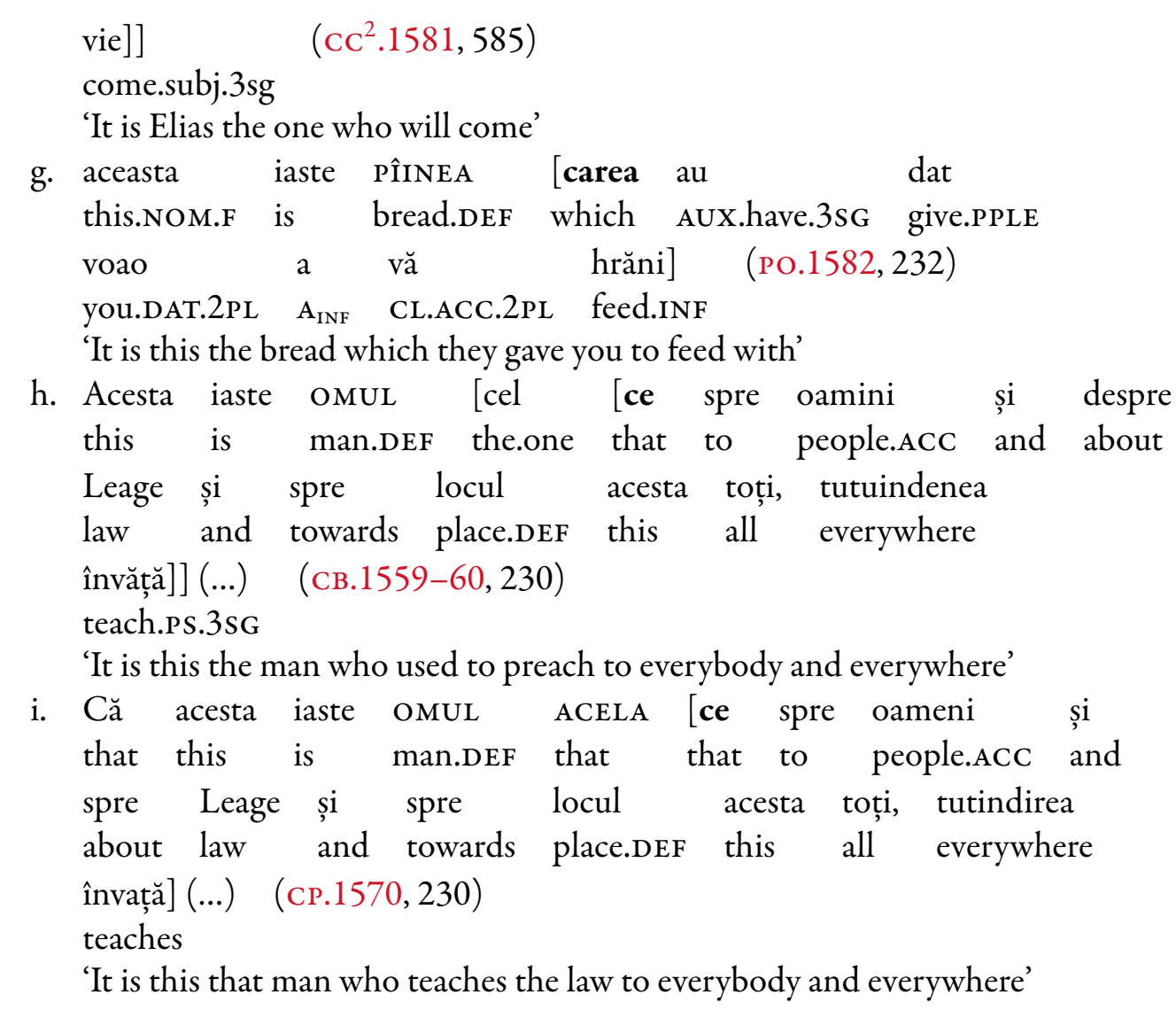

Example (12) is interesting due to the different organization of the constituents in the structure (the copula is in front of the focalized XP), due to the negation and to the semantic nature of the focalized $\mathrm{XP}$ (it is an indefinite quantifier embedded in a phrase with empty head). In the same time, the example is peculiar because the empty head of the DP makes it difficult to be framed either into the prototypical pseudo-cleft pattern (12a) or into the reversed pseudo-cleft pattern (with an antecedent relative clause) $\left(12 a^{\prime}\right):$

a. Den aceastea toate, nu-s
form these
n-au

'Out of all these, there are not many those that came up in Romanian from Serbian and Greek'

a'. Den aceastea toate, nu-s MULTE [C̆̆RȚI] [cele]

from these all not=are many books those

[care n-au ieșit în limba rumânească

which not=AUX.have.3SG arise.PPLE in language Romanian

den ceale cărți sîrbești și grecești]. (Po.1582, Prefaţă, $3^{\mathrm{r}}$ )

from those books Serbian and Greek

'Out of all these, there are not many books those that came up in Romanian from Serbian and Greek'

Other constructions may be also included into the category of hybrid clefts: interrogative clauses as in example (13), negative constructions like $(14 \mathrm{a}, \mathrm{b})$, where the focalized element is a covert negative quantifier, 
or reduced relative clauses like (15a) and elliptical constructions as in (15b); they all share the emphasis, the focalization of a constituent and its placement into a structure that 'breaks' the canonical organization of the sentence.

(13) Mirară-se toți ceia ce auzia și grăiia: amaze.PS.3PL=CL.REFL.3PL all those that hear.IMP.3PL and SAY.IMP.3PL

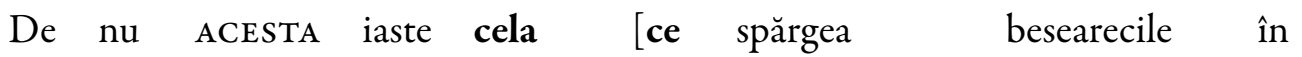
if not this is the.one that break.IMP.3SG churches.DEF in Ierusalim ceia ce meniia numele acesta ...]? (CP.1570, 97) Jerusalem those that foredoom.IMP.3PL name.DEF this 'All who heard (this) were amazed and they said: isn't it this the one who used to break the churches in Jerusalem and that was meant to bear this name?'

a. $\mathrm{Nu}$ iaste $\sqrt{ }[\mathrm{ca}$ să rîdice sicriiul lui not is in.order.to S $\breve{A}_{\text {SUBJ }}$ lift.SUBJ.3SG coffin.DEF LUI.GEN

Dumnezău], fără numai leviții (Bв.1688,298)

God without only Levites.DEF

'There is no one but the Levites who are supposed to lift God's coffin'

b. $\mathrm{Nu}$ iaste $\sqrt{ }$ cel $[\mathrm{ce}$ să știe calea ei], nici $\sqrt{ }$ not is that that $\breve{S}_{\text {SUBJ }}$ know.SUBJ.3SG way.DEF her nor cel [ce să pomenească cărarea ei $] \quad$ (Bв.1688, 635) the.one that $\breve{A}_{\text {SUBJ }}$ mention.SUBJ.3SG path.DEF her 'There is no one but him that is supposed to know it's way or mention it's path'
a. $\mathrm{Fu}$ PETRU cercetîndu toți a deștenge cătră be.PS.3sg Peter ask.ger everybody.ACC $\mathrm{A}_{\mathrm{INF}}$ go.INF towards svinții ceia ce viia întru Lida (CP.1570, 100) saints.DEF those who live.IMP.3PL in Lida 'It was Peter who asked them all to go to the saints that lived in Lida'
b. Era FIIUL LUI cela $\sqrt{ }$ mai marele la sat. be.IMP.3SG son.DEF his that more great.DEF at village 'It was his son who was the greatest in the village'

\section{Conclusions}

The analysis of the corpus showed that, unlike MR, the cleft sentences patterns are more diverse in OR, both in terms of the structure organization and in terms of the focalizing procedures. The absence in the OR corpus of basic pseudo-clefts (much frequent in MR as compared to the reversed ones) seems to confirm the intuition that the pseudo-cleft pattern in MR is based on a French or Italian model and that it is relatively recent. On the other hand, the variety of these constructions (including the hybrid clefts, which may be influenced by some foreign models) show that the cleft constructions are not accidental in $\mathrm{OR}$, and that they were a viable strategy for the focalization of a constituent.

\section{Bibliography}

\section{A. Corpus}

A.1620 = Alexandria, in Zgraon, Fl. (ed.), Cele mai vechi cărți populare în literatura română, vol. 11, Fundația Națională pentru Ştiință și Artă, București, 2006.

AD.1722-5 = Antim Ivireanul, Didahii, in Antim Ivireanul, Opere, ed. G. Ștrempel, Editura Minerva, București, 1972, p. 1238.

AU.1700 = Axinte Uricariul, Cronica paralelă a Țării Românești și a Moldovei, ediție critică și studiu introductiv de Gabriel Ștrempel, Editura Minerva, București, 1993. 
Bв.1688 = Biblia adecă Dumnezeiasca Scriptură a Vechiului și Noului Testament, tipărită întîia oară la 1688 în timpul lui Șerban

Vodă Cantacuzino, Domnul Țării Românești, Editura Institutului Biblic, București, 1977.

CazV.1643 = Varlaam, Cazania, ed. J. Byck, Fundația Regală pentru Literatură și Artă, București, 1943, p. 1-506.

Св.1559-60 = Codicele Bratul, ed. Al. Gafton, [online].

CC $^{2} .1581$ = Coresi, Cartea cu învățătură, ed. S. Pușcariu \& Al. Procopovici, Atelierele Grafice Socec, București, 1914.

CD.1698 = Dimitrie Cantemir, Divanul, in D. Cantemir, Opere complete, I, Divanul, ed. V. Cîndea, Editura Academiei RSR,

București, 1974, p. 103-405.

CP.1570 = Coresi, Psaltirea slavo-română (1577) in comparație cu psaltirile coresiene din 1570 și din 1589, ed. S. Toma, Editura

Academiei RSR, București, 1976, p. 35-662.

FD.1592-604 = Floarea darurilor, in Roman Moraru, Al. (ed.) (1996). Cele mai vechi cărți populare în literatura română, 1 ,

Editura Minerva, București, p. 119-182.

PH.1500-1510 = Psaltirea Hurmuzaki, ed. I. Gheție \& M. Teodorescu, Editura Academiei Române, București, 2005.

Po.1582 = Palia de la Orăștie, ed. V. Pamfil, Editura Academiei RSR, București, 1968.

Prav.1581 = Pravila ritorului Lucaci, ed. I. Rizescu, Editura Academiei RSR, București, 1971, p. 161-183.

\section{B. References}

Akmajian, A. (1970). On Deriving Cleft Sentences from Pseudo-Cleft Sentences, in “Linguistic Inquiry”, vol. 1, iss. 2, p. 149-168, [online].

Boškovic, Ž. (1997). Pseudoclefts, in "Studia Linguistica”, vol. 51, iss. 3, p. 235-277, Crossref.

Collins, P. (1991). Clefts and Pseudo-Cleft Constructions in English, Routledge, London \& New York.

Declerck, R. (1984). The pragmatics of it-clefts and WH-clefts, in "Lingua”, vol. 64, iss. 4, p. 251-289, Crossref.

Declerck, R. (1988). Studies in Copular Sentences, Clefts and Pseudo-clefts, Foris Publications, Holland/USA, Crossref.

Gheorghe, M. (2004). Propoziția relativă, Editura Paralela 45, Pitești.

Gundel, J.K. (1977). Where do cleft sentences come from?, in "Language", vol. 53, iss. 3, p. 543-559, Crossref.

Halliday, M.A.K. (1985). An Introduction to Functional Grammar, Edward Arnold, London.

Hartmann, K. \& Tonjes V. (eds) (2013). Cleft Structures, John Benjamins Publishing Company, Amsterdam, Crossref.

Hedberg, N. (2013). Multiple focus and cleft sentences, in Hartmann \& Tonjes (2013), p. 227-250, Crossref.

Higgins, F. R. (1979). The Pseudo-cleft Construction in English, Garland Publishing, New York, Crossref.

Huddlestone, R., Pullum, G. K. et al. (2002). The Cambridge Grammar of the English Language, Cambridge University Press.

Iatridou, S. \& Varlokosta, S. (1998). Pseudoclefts crosslinguistically, in "Natural Language Semantics", vol. 6, iss. 1, p. 3-28, Crossref.

Jespersen, O. (1937/1984). Analytic Syntax, The University of Chicago Press.

Lambrecht, K. (2001). A Framework for the Analysis of Cleft Constructions, in "Linguistics", vol. 39, iss. 3, p. 463-516, Crossref. Pană Dindelegan, G. (ed.) (2013). The Grammar of Romanian, Oxford University Press.

Prince, E. F. (1978). A comparison of Wh-clefts and it-clefts in discourse, in "Language", vol. 54, iss. 4, p. 883-906, Crossref.

Prince, E. F. (1981). Toward a taxonomy of given-new information, in Cole, P. (ed.), Radical Pragmatics, Academic Press, New York, p. 223-255.

Reeve, M. (2011). The syntactic structure of English clefts, in "Lingua”, vol. 121, iss. 2, p. 142-71, Crossref.

Reeve, M. (2012). Clefts and their Relatives, John Benjamins Publishing Company, Amsterdam, Crossref.

Șerbănescu, A. (1996). Construcții scindate, in "Limba Română”, vol. 35, iss. 1, p. 3-10. 